\title{
Patient Journey Mapping To Investigate Quality and Cultural Safety in Burn Care for Aboriginal and Torres Strait Islander Children and Families - Development, Application and Implications
}

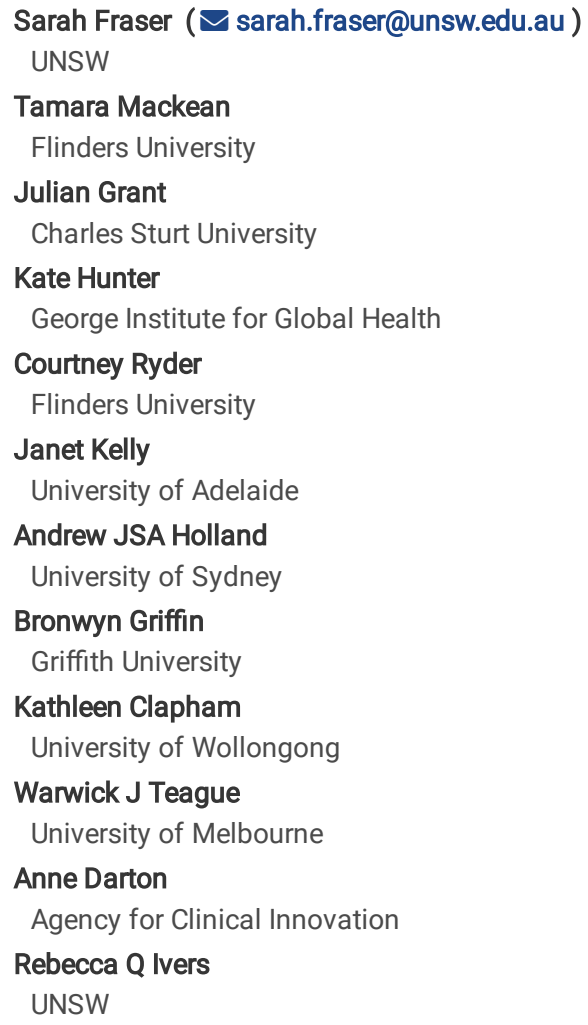




\section{Abstract \\ Background}

Quality and safety in Australian healthcare is inequitably distributed, highlighted by gaps in the provision of quality care for Aboriginal and Torres Strait Islander children. Burns have potential for long-term adverse outcomes, and quality care, including culturally safe care, is critical to recovery. This study aimed to develop and apply an Aboriginal Patient Journey Mapping (APJM) tool to investigate the quality of healthcare systems for burn care with Aboriginal and Torres Strait Islander children.

\section{Study Design}

Interface research methodology, using biomedical and cultural evidence, informed the modification of an existing APJM tool. The tool was then applied to the journey of one family accessing a paediatric tertiary burn care site. Data were collected through yarning with the family, case note review and clinician interviews. Data were analysed using Emden's core story and thematic analysis methods. Reflexivity informed consideration of the implications of the APJM tool, including its effectiveness and efficiency in eliciting information about quality and cultural safety.

\section{Results}

Through application of a modified APJM tool, gaps in quality care for Aboriginal and Torres Strait Islander children and families were identified at the individual, service and system levels. Engagement in innovative methodology incorporating more than biomedical standards of care, uncovered critical information about the experiences of culturally safe care in complex patient journeys.

\section{Conclusion}

Based on our application of the tool, APJM can identify and evaluate specific aspects of culturally safe care as experienced by Aboriginal and Torres Strait Islander peoples and be used for quality improvement.

\section{Background}

Significant focus and effort are being directed towards ensuring quality healthcare worldwide [1]. In Australia quality standards and accreditation measures [2] influence care provision and regulate healthcare efficiency and effectiveness. Engagement in quality improvement (QI) supports healthcare services and providers to constructively critique the healthcare they provide and implement improvement activities [1]. Often, improvement is focused on performance and limitations of healthcare services, with process mapping and clinical redesign as QI methods [3, 4]. These methods often lack inclusion of patient experiences, with efficiency processes not always enhancing patient experiences or improving health outcomes.

In Australia, quality healthcare for Aboriginal and Torres Strait Islander peoples has increasingly been linked to cultural safety [5] and competency of healthcare services [6, 7]. The revised National Safety and Quality Health Service standards [8] for health services now include six actions specific to the health of Aboriginal and Torres Strait Islander peoples' and the cultural competency of tertiary healthcare services. This is the result of an increasing recognition that quality healthcare must consider both cultural $[9,10]$ and clinical safety, ensuring that all needs of an individual and family are met. This concept is supported by the Australian Safety and Quality Framework for Health Care [11] which positions consumer-centeredness as one of three key indicators of quality.

Many Aboriginal and Torres Strait Islander peoples have a holistic model of health and healing that is not fully responded to or always understood by Australia's dominant biomedical health system [10]. The multi-dimensional holistic model includes considerations of physical, psychological, social health and wellbeing, spirituality, and cultural integrity aspects [12]. When cultural and spiritual aspects of health and healing are considered in the context of healthcare, health outcomes for Aboriginal and Torres Strait Islander peoples are improved, and an experience of culturally safe care can be achieved [5]. The theory of cultural safety, originally developed in New Zealand [13], has since been applied to healthcare in Australia [5,9]. The principles of culturally responsive and respectful care have been adapted further, and have been used both in assessing quality in standards [14] and in Australian healthcare policy [15]. The cultural safety principles (reflexivity, dialogue, power imbalances, decolonisation and regardful care) are developed from First Nations knowledges and generations of lived experience [16].The principle of decolonisation sets cultural safety apart from other cultural frameworks as it is focussed on peoples who have been impacted by colonisation [16], and is different from cultural competency which takes an individualised perspective, and focusses on minority populations more broadly [6]. While many providers in the Australian mainstream healthcare system endeavour to provide culturally competent healthcare [6], it is unclear as to whether this leads to an experience of culturally safe care for consumers.

Reliably accessible patient-centred healthcare is a health inequity Aboriginal and Torres Strait Islander peoples face [17, 18], suggesting racism (in all forms), or at the very least, deficits in quality. Racism can be systemic, interpersonal or internalised [19]. Aboriginal and Torres Strait Islander peoples experiences of being judged, misunderstood, and stereotyped by healthcare providers in Australia's mainstream healthcare system causes distress and disengagement of both individuals and families [20]. Further, communication breakdown in healthcare environments results in difficulty assessing symptoms, eliciting signs, reaching accurate diagnoses and providing effective care [21]. Institutional racism in health systems creates structural barriers and impacts at a population level. Together, these quality deficits contribute to inequitable health outcomes for Aboriginal and Torres Strait Islander peoples. 
Aboriginal and Torres Strait Islander children experience burn injury at disproportionally higher rates than non-Indigenous children, and have in longer lengths of inpatient care [22]. Such disparities are one example of the many multifaceted and complex disparities experienced by Aboriginal and Torres Strait Islander families more broadly. Further, these disparities are intergenerational and need to be understood in the context of the family and community. So, while accreditation processes seek to ensure quality healthcare in tertiary settings [2], including those with specific cultural competency [8] and burn care [23] components, a single tool that specifically assesses both the clinical and cultural quality of burn care for Aboriginal and Torres Strait Islander children and families is lacking.

Patient Journey Mpping (PJM) is a quality assessment method used to better understand and provide a detailed account of patient healthcare journeys [24]. PJM has previously described the journey stages in which the healthcare system fails or succeeds to provide quality and responsive care to patients, and is therefore a useful method to appraise and guide organisations' approaches to care $[3,4]$. It highlights barriers and enablers to care from the perspective of both the recipient and provider of healthcare [3] and enables comparisons of critical points in time with existing best practice models and guidelines. Aboriginal PJM (APJM) can provide mechanisms for identifying gaps and facilitating improvements in Aboriginal patient journeys by depicting the complexities inherent in healthcare, with a focus on QI [25]. APJM may therefore provide an opportunity to investigate the lived experience of families of children with a burn injury within and across the health system and enable a proper exploration of disparities that are not simple in nature. This paper aims to examine the critical components relevant to, and modification of an existing APJM tool [26], specifically for Aboriginal and Torres Strait Islander patients to assess quality and cultural safety in the burn care journey of Aboriginal and Torres Strait Islander families for the purpose of QI.

\section{Methods}

\subsection{Ethical Considerations}

Ethics approval for this study was received from the: Aboriginal Health Research Ethics Committee; Women's \& Children's Health Network Human Research Ethics Committee; Flinders University SBREC; Central Australian Human Research Ethics Committee; Human Research Ethics Committee of Northern Territory; Department of Health and Menzies School of Health; and the Department of Health Human Research Ethics Committee. All participants provided written informed consent.

The research was guided by the National Health and Medical Research Council's values and ethics for doing research with Aboriginal communities. These strategies were upheld throughout the research. The primary researcher (SF) worked in partnership with Waljen woman, mentor, PhD supervisor and author (TM) to design and undertake the project. Furthermore, this research forms part of a larger study [27] which is guided by an Aboriginal and Torres Strait Islander reference group.

\subsection{Theoretical framework}

Cultural safety and knowledge interface research informs the methodological constructs underpinning this research and provides a space to bring together the health and healing constructs of Aboriginal and Torres Strait Islander peoples and key indicators for western biomedical burn care quality [28-30]. This is a space without notions of dominance or superiority, within which mutual respect, shared benefits, human dignity and discovery provide an opportunity for new and relative knowledge production [28, 29, 31]. This research engages a qualitative study design [32] with Indigenous ways of knowing, being and doing [33] in the context of evaluating the quality and cultural safety of healthcare systems and services for burn care with Aboriginal and Torres Strait Islander children and families using APJM $[25,26]$.

\subsection{Developing the APJM Tool}

For development of the APJM tool, we looked at the biomedical evidence informing burn care currently in Australia and found that acute burns, including those involving joints or young children, typically require specialist tertiary healthcare [34]. In Australia, these specialist tertiary services are metropolitan. We also found that burn care is best delivered by multi-disciplinary teams [35] comprising many healthcare professionals, who each bring a unique skill set, focus and contribution to care. Key professions in these teams include: nursing, occupational therapy, physiotherapy, medical, dietetics, psychology, and social work [35-38]. We also found that burn care can be separated into distinct critical points in time from a biomedical perspective, evident in the existing models that guide burn care [36] and research evidence [34]. These critical points, whilst referred to differently, include: the injury; emergency care; ambulatory care; admission; in-patient care; discharge; and rehabilitation. We found the evidence base for the models of burn care used in Australia [36-40] varied, however commonalities in treatment existed across the models. All evidence was incorporated into the APJM tool, and to consolidate and gain consensus on inclusion, input from clinicians and policy makers was sought through roundtables and review of the tool.

Consideration of the health and healing constructs of Aboriginal and Torres Strait Islander peoples for inclusion in the APJM tool was through use of the theoretical constructs $[13,29,41]$ and engagement of the Aboriginal co-researchers who contributed to knowledge of how these could be applied. We found it was important for holistic philosophies and Indigenous knowledges [41] to be incorporated throughout the APJM tool. We also determined that the critical time points of burn care for families were less rigid points than those associated with biomedical burns care and were reflective of family needs.

The biomedical and cultural evidence was brought together at the knowledge interface, in order to take account different influences at different levels in complex health systems, all of which are interrelated and not independent of one another [29] and are especially important given factors informing burn care in Australia[Fraser]. We found that by developing the APJM tool at the knowledge interface, we were able to bring together, the experience of the recipient of care, the perspective of healthcare service, and the influence of the healthcare system in a manner which encompassed mutual respect, shared benefit, discovery, and dignity $[29,30,41]$. 
The compilation of this information into a single APJM tool was facilitated by use of a single spreadsheet file with two components: one to assess the provision of quality care compared with the biomedical evidence (Supplementary Material 1); and a second to record the burn care journey in-line with Aboriginal and Torres Strait Islander constructs of health and healing (Supplementary Material 2). A roundtable of researchers, clinicians and Aboriginal healthcare professionals critically refined the tool after which endorsement for application of the tool was sought.

\subsection{Application of the APJM tool}

The mapping process, through application of the APJM tool to investigate the quality of healthcare systems and services for burn care with Aboriginal and Torres Strait Islander children included two phases: recruitment, and data collection and analysis.

An outer metropolitan family was recruited to participate in the application of the APJM tool. The participant, an Aboriginal child whose family accessed tertiary burn care, was chosen from an overarching study investigating burn injury in Aboriginal and Torres Strait Islander children [27]. The role of the main researcher in applying the tool (author SF), was a PhD candidate, external to the tertiary healthcare site, yet linked to the site through their participation in the overarching study [27]. Clinicians identified through case note review and involved in the provision of care were also invited to participate.

Data collection and analysis for the mapping process entailed four main stages, which were completed iteratively, but not sequentially (Fig. 1). These included yarning with the family, case note review, structured interviews with key burn care clinicians, and collaborative data analysis. In line with interface research [28, 29], Indigenous knowledges and understandings were employed through research yarning with authors TM and CR. Both of whom are Aboriginal woman and health researchers, linked closely through a cultural mentorship role to the main researcher (Author SF).

For the yarning with family, author SF was accompanied by author CR into the family's home. Yarning [42] is an Indigenous cultural form of conversation and data gathering tool in research. This yarn was transcribed verbatim and analysis of this interview was through use of Emden's core story analysis [26, 43] whereby a series of processes led to the creation of a de-identified core story that the participant confirmed for accuracy. These data were also analysed thematically using deductive methods [32] and input into the APJM tool spread sheets. Further synthesis of the yarning data provided the means to assess cultural safety and associated risk for the participating family. Consistent with the coming together of Indigenous and western knowledge, these processes contribute to reliability of data analysis and demonstrate our application of interface research.

The case note review and structured interviews with key burn care clinicians captured the quality components of the approaches to burn care, and the perspectives of healthcare providers. These data were also input into the APJM tool spreadsheets.

\section{Results}

\subsection{Effectiveness of the modified APJM tool in identifying gaps in quality and cultural safety}

\subsubsection{Experience of the individual child and family}

The APJM tool enabled the assessment of quality regarding the individual family's experience of care in the healthcare system (Table 1). The family perceived that they experienced disrespectful care; they felt isolated and helpless during their child's inpatient stay and vulnerable on discharge. The family also identified significant gaps relating to follow-up care and ease of access to rehabilitation. Synthesis of the yarning data (Supplementary Material 3) informed by the principles of cultural safety identified that care was most likely experienced as culturally high risk at the 'sustained interface' and 'going home' phase (Table 2). Such gaps in quality acknowledge the individual's experience of care as a result of fundamental differences in knowledge and understanding as reflected in the burn care health system.

\subsubsection{Perspective of health care providers}

Mapping data identified that healthcare providers were neither resourced nor supported to provide best care following patient discharge, and there were limited options for referral to community based social workers (Table 1). APJM also showed healthcare providers mostly conform to the evidence underpinning medical aspects of burn care. There was no AHW employed at the site, nor was any input from a psychologist involved in the care (Table 3 ).

\subsubsection{Assessment of the health system}

The APJM tool was able to identify where there are gaps in the healthcare system regarding quality of burn care for Aboriginal and Torres Strait Islander children and families. Burn care was mostly delivered in line with the prescribed indicators of biomedical quality; e.g. first aid was given, burn specialist assessment was within the stipulated time-frame and multi-disciplinary care was provided. However, contribution by the Aboriginal/Indigenous liaison officer (A/ILO) was both late in the timeline of clinical care, and limited. Access to rehabilitation services outside of the tertiary healthcare environment was reduced and did not meet standards (Table 3).

\section{Discussion}

\subsection{Implications of the APJM tool}

The innovation in using knowledge interface methodology and Indigenous research methods, combined with the principles of cultural safety and guided specifically by the principle of reflexivity [44] as it relates to researchers and health care with Aboriginal and Torres Strait Islander people, enabled the implications of developing and applying the APJM to be considered. Engagement in reflexive practice provided a space to inform this process from a culturally safe and holistic health standpoint. 
Through application of the APJM tool, we have shown feasibility of its use in the burn care journeys of Aboriginal and Torres Strait Islander families such that it enables an exploration of the multiple layers of experience in the health care system. This includes the system, service and individual with a holistic model. With the engagement of Indigenous knowledge, we have been able to capture gaps in quality that relate to more than biomedical quality evidence. This APJM research has shown that while complex disparities being experienced by Aboriginal and Torres Strait Islander children and families, quality is able to be explored thoroughly when using tools that address all aspects of quality. With these aspects considered, APJM is time intensive and challenging to engage clinicians.

Application of the APJM tool was undertaken over four months (approximately $120 \mathrm{hrs}$ ) in 2018 . The tool was lengthy and could be reduced by the inclusion of only those standards specific to the jurisdiction where the tool is being used. Testing of the tool with regional/remote families and with older children is required. Recruitment and engagement of family members in mapping was enhanced by existing relationships with the mother. Having the grandparents present at the family interview contributed to a deeper understanding. The family interview was facilitated with an Aboriginal woman as a co-researcher, supporting ethical research. The interview was conducted in the family home, on the basis the family were more likely to feel secure in their own space, and dinner was supplied though study funds.

\subsection{APJM for use in complex quality investigations}

Results from this study show existing APJM tools [26] are able to be modified to investigate quality and cultural safety in burn care for Aboriginal and Torres Strait Islander children and families in a tertiary setting. Through application of the tool, new levels of understandings and recommendations for changes in practice which can alter the experience of those receiving the care were able to be identified. The implications of engaging an innovative approach through interface research show quality improvement is able to be considered from more than regulation or performance perspective. An exploration of complex disparities was enabled that incorporated patient experiences at the individual, service and system level. This study was limited due to being only one case with no control, and a similar study with a non-Indigenous family may have generated similar issues.

These findings confirm that retrospective data is useful in assessing healthcare quality in patient journeys, as well as interactions between various components of quality in this setting. The APJM tool enabled assessment of performance, regulatory constraints and patient experience in tandem. Analysis of these data, using Emden's analysis method [43,45] and thematic analysis [32] gave insight into the families' journey of quality in burn care. The tool also gave burn healthcare providers the opportunity to externalise and reflect on their capabilities and the care they provide. As a result, use of APJM provided a space for healthcare providers to consider how to improve and innovate within their own practice through reflexivity. While existing professional relationships with the lead burns nurse made access to relevant clinicians more successful due to this nurse's influence on facilitating clinician availability, it was sometimes difficult to engage busy clinicians with the mapping process when seeking to clarify and understand key points and interactions within the journey. This reflects the findings of the Managing Two World Together Project where clinician engagement was promoted by collaborative involvement in the research and development of tools, as compared with externally-developed tools imposed upon them [26]. Therefore provision of more information on the processes and aims of APJM may enhance participation by busy clinicians.

This preliminary analysis did not include responding to the findings to improve communication, reduce perceived differential treatment or enhance access to post-discharge care. Further considerations need to be made to determine how best to work with multidisciplinary burns teams and healthcare services to effectively plan and implement improvements in burn care for Aboriginal and Torres Strait Islander children and families. Existing QI frameworks and engagement in reflexivity by healthcare practitioners may be key aspects of future approaches, however there does exist opportunities for immediate QI considerations. This includes the employment of Aboriginal Liaison Officers as part of burn teams, appropriate resource allocations and increased focus on Aboriginal and Torres Strait Islander aspects to burn care in team meetings (clinical and research).

\section{Conclusions}

The APJM tool aims to facilitate the exploration of complex patient journeys following a burn injury, the increase in knowledge of what works well and what needs improvement in the healthcare system for Aboriginal and Torres Strait Islander children and families. Whilst many methods and methodological approaches to improve the quality and safety of healthcare exist, very few address the knowledge interface of Indigenous and western health knowledges, nor provide opportunity for children to have a voice. In undertaking this study, we have developed a tool enabling research of burn care quality at the knowledge interface, with explicit consideration of more holistic, fluid and culturally safe models of healthcare.

\section{List Of Abbreviations}

ILO

Indigenous Liaison Officer, ALO:Aboriginal Liaison Officer, APJM:Aboriginal Patient Journey Mapping, Ql:Quality Improvement.

\section{Declarations}

\section{Ethics approval and consent to participate}

Aboriginal Health Research Ethics Committee 04-14-572; Women's \& Children's Health Network Human Research Ethics Committee HREC/14/WCH/65; Flinders University SBREC Project OH-00065; Northern Territory. Central Australian Human Research Ethics Committee HREC-14-253. Human Research Ethics Committee of Northern Territory Department of Health and Menzies School of Health 2014-2214; National. Department of Health Human Research Ethics Committee 39/2014. All methods were performed in accordance with the NHMRC 2018 National Statement on Ethical Conduct in Human Research and participants provided written informed consent. 


\section{Consent for publication}

Not applicable.

\section{Availability of data and materials}

The datasets generated during and/or analysed during the study are not publicly available due to ethical restrictions but may be available from the corresponding author on reasonable request.

\section{Competing interests}

All authors declare no competing interests.

\section{Funding}

The project is funded by the National Health and Medical Research Council of Australia (grant number APP1059038). Author KH is supported by a NSW Health Early Mid-Career Fellowship. The researchers were independent from the funder.

\section{Authors' contributions}

SF designed the study in conjunction with TM, JG, KH and RI. TM and CR mentored SF throughout the project and provided input into project design, data collection and data analysis. SF and CR collected the data and analysed it in conjunction with all other authors. SF, TM, JG, KH, CR and RI contributed to the review of the literature that informed the paper. JK, AH, BG, KC, WT and AD all provided specific technical advice in developing the tool. SF and TM wrote the first draft of the manuscript and all authors read and approved the manuscript.

\section{Acknowledgments}

We acknowledge the Aboriginal people and communities who were part of this research and contributed to author SF's learnings in this area. In particular we acknowledge the family who shared their story and the clinicians who participated in the application of the APJM tool presented here.

\section{References}

1. Hayes, C.W., Batalden, P.B., and Goldmann, D., A 'work smarter, not harder' approach to improving healthcare quality. BMJ Qual Saf, 2015. 24(2): p. 100102.

2. The Australian Council on Healthcare Standards. Available from: https://www.achs.org.au/.

3. Ben-Tovim, D.I., et al., Patient journeys: the process of clinical redesign. Medical Journal of Australia, 2008. 188(S6): p. S14-S17.

4. Johnson, J.K., et al., Searching for the missing pieces between the hospital and primary care: mapping the patient process during care transitions. BMJ Qual Saf, 2012. 21(Suppl 1): p. i97-i105.

5. Laverty, M., McDermott, D.R., and Calma, T., Embedding cultural safety in Australia's main health care standards. The Medical journal of Australia, 2017. 207(1): p. 15-16.

6. Bainbridge, R., et al., Cultural competency in the delivery of health services for Indigenous people. 2015.

7. Commonwealth of Australia, National Aboriginal and Torres Strait Islander Health Plan 2013-2023. 2013.

8. Australian Commission on Safety and Quality in Health Care, The National Safety and Quality Health Service Standards, 2nd Edition, 2017: Sydney.

9. Taylor, K., and Guerin, P., Health care and Indigenous Australians: cultural safety in practice, 2nd edition. 2014, Australia: Macmillan Education.

10. Best, O. and B. Fredericks, Yatdjuligin: Aboriginal and Torres Strait Islander nursing and midwifery care. 2017: Cambridge University Press.

11. Australian Commission on Safety and Quality in Healthcare, Australian Safety and Quality Framework for Health Care 2010.

12. Australian Indigenous Doctors' Association and Centre for Health Equity Training Research and Evaluation, Health Impact Assessment of the Northern Territory Emergency Response. Canberra: Australian Indigenous Doctors' Association, 2010.

13. Ramsden, I., Cultural safety and nursing education in Aotearoa and Te Waipounamu. 2002, Victoria University of Wellington Wellington.

14. Fraser, S., et al., Burn injury models of care: A review of quality and cultural safety for care of Indigenous children. Burns, $2018.44(3)$ : p. 665-677.

15. Mackean, T., et al., A framework to assess cultural safety in Australian public policy. Health Promotion International, 2019.

16. Ryder C, Mackean T, Ullah S, Burton H, Halls H, McDermott D, and Edmondson W., Development and validation of a questionnaire to measure attitude change in health professionals after completion of an Aboriginal health and cultural safety training Programme. The Australian Journal of Indigenous Education. 2019 Aug;48(1):24-38.

17. Dwyer, J., et al., Equitable care for indigenous people: Every health service can do it. Asia Pacific Journal of Health Management, 2016. 11(3): p. 11.

18. Cunningham, J., Diagnostic and therapeutic procedures among Australian hospital patients identified as Indigenous. Medical Journal of Australia, 2002. 176(2): p. 58-62.

19. Paradies Y. Racism and Indigenous Health. Oxford University Press; 2018.

20. Larson, A., et al., It's enough to make you sick: the impact of racism on the health of Aboriginal Australians. Australian and New Zealand journal of public health, 2007. 31(4): p. 322-329. 
21. Artuso, S., et al., Factors influencing health care utilisation among Aboriginal cardiac patients in central Australia: a qualitative study. BMC Health Services Research, 2013. 13(1): p. 83.

22. Ryder C, Mackean T, Hunter K, Towers K, Rogers K, Holland AJA, et al. Factors contributing to longer length of stay in Aboriginal and Torres Strait Islander children hospitalised for burn injury. Injury Epidemiology. 2020;7(1):52.

23. American Burn Association. Burn Center Verification. Available from: http://ameriburn.org/quality-care/verification/.

24. McCarthy, S., et al., An integrated patient journey mapping tool for embedding quality in healthcare service reform. Journal of Decision Systems, 2016. 25(sup1): p. 354-368.

25. Kelly, J., et al., Bottling knowledge and sharing it - using patient journey mapping to build evidence and improve Aboriginal renal patient care. Renal Society of Australasia Journal 2016. 12(2): p. 48-55.

26. Kelly, J., et al., Coproducing Aboriginal patient journey mapping tools for improved quality and coordination of care. Australian Journal of Primary Health, 2017. 23: p. 536-542.

27. Ivers, R.Q., et al., Understanding burn injuries in Aboriginal and Torres Strait Islander children: protocol for a prospective cohort study. BMJ open, 2015. 5(10): p. e009826.

28. Durie, M., Indigenous knowledge within a global knowledge system. Higher Education Policy, 2005. 18(3): p. 301-312.

29. Durie, M., Understanding health and illness: research at the interface between science and indigenous knowledge. International journal of epidemiology, 2004. 33(5): p. 1138-1143.

30. Ryder C, Mackean T, Coombs J, Williams H, Hunter K, Holland AJ, et al. Indigenous research methodology-weaving a research interface. International Journal of Social Research Methodology. 2020;23(3):255-67.

31. Pyrch, T. and M.T. Castillo, The sights and sounds of indigenous knowledge. Handbook of action research: Participative inquiry and practice, 2001: p. 379-385.

32. Patton, M.Q., Qualitative evaluation and research methods. 2014, United States of America: SAGE Publications, inc.

33. Martin, Karen L. \& Mirraboopa, Booran (2003) Ways of knowing, being and doing: A theoretical framework and methods for indigenous and indigenist research. Journal of Australian Studies, 27(76), pp. 203-214.

34. Kim, L.K., H.C. Martin, and A.J. Holland, Medical management of paediatric burn injuries: best practice. Journal of paediatrics and child health, 2012. 48(4): p. 290-295.

35. D'cruz, R., H.C. Martin, and A.J. Holland, Medical management of paediatric burn injuries: Best practice part 2. Journal of paediatrics and child health, 2013. 49(9): p. E397-E404.

36. Women's and Children's Hospital Paediatric Burns Service, Women's and Children's Hospital Paediatric Burns Service Guidelines, Women's and Children's Hospital Paediatric Burns Service, Editor. 2014.

37. Department of Health Western Australia, Burn Injury Model of Care. Perth: Health Networks Branch, Department of Health Western Australia, Editor. 2009.

38. Agency for Clinical Innovation, Model of Care NSW Statewide Burn Injury Service, Agency for Clinical Innovation, Editor. 2011.

39. Australian \& New Zealand Burns Association. ANZBA Referral Criteria. Available from: http://anzba.org.au/care/referral-criteria/.

40. Australian \& New Zealand Burns Association. First Aid. Available from: https://anzba.org.au/care/first-aid/

41. Milroy, H., Children are our future: Understanding the needs of aboriginal children and their families, in Infants of Parents with Mental IIness: Developmental, Clinical, Cultural and Personal Perspectives. 2008, Australian Academic. p. 121-140.

42. Bessarab, D. and B. Ng'andu, Yarning about yarning as a legitimate method in Indigenous research. International Journal of Critical Indigenous Studies, 2010. 3(1): p. 37-50.

43. Emden, C., Conducting a narrative analysis. Collegian, 1998. 5(3): p. 34-39.

44. Wilson, A., Addressing Uncomfortable Issues: Reflexivity as a Tool for Culturally Safe Practice in Aboriginal and Torres Strait Islander Health, 2014, The Australian Journal of Indigenous Education, Volume 43 Issue 2, DOI: https://doi.org/10.1017/jie.2014.24.

45. Kelly, J., et al., Managing two worlds together: Stage 2-patient journey mapping tools. 2012.

\section{Tables}


Table 1

- Results of PJM tool Spreadsheet Two. Indigenous concepts of health and healing and family and healthcare professional perspectives.

\begin{tabular}{|c|c|c|c|c|c|c|c|c|}
\hline $\begin{array}{l}\text { Points in time - } \\
\text { headings to } \\
\text { elicit holistic } \\
\text { views of health }\end{array}$ & Crisis & Getting help & $\begin{array}{l}\text { Leaving } \\
\text { competing } \\
\text { obligations }\end{array}$ & $\begin{array}{l}\text { Confronting } \\
\text { the system }\end{array}$ & $\begin{array}{l}\text { Sustained } \\
\text { Interactions }\end{array}$ & Being away & Going home & $\begin{array}{l}\text { Confronting } \\
\text { competing } \\
\text { needs }\end{array}$ \\
\hline $\begin{array}{l}\text { Caregiver's } \\
\text { perspective }\end{array}$ & $\begin{array}{l}\text { Accessible } \\
\text { and } \\
\text { appropriate } \\
\text { care. }\end{array}$ & $\begin{array}{l}\text { Accessible } \\
\text { and } \\
\text { appropriate } \\
\text { care. }\end{array}$ & $\begin{array}{l}\text { Care } \\
\text { arranged for } \\
\text { sibling and } \\
\text { family } \\
\text { contacted. }\end{array}$ & $\begin{array}{l}\text { Identification } \\
\text { question } \\
\text { asked. } \\
\text { Felt scared } \\
\text { and ignored. } \\
\text { Social } \\
\text { worker } \\
\text { provided } \\
\text { support. }\end{array}$ & $\begin{array}{l}\text { Communication } \\
\text { was } \\
\text { inconsistent. } \\
\text { Felt judged for } \\
\text { not staying in } \\
\text { the hospital. } \\
\text { Unable to work } \\
\text { with } \\
\text { subsequent } \\
\text { extreme } \\
\text { financial } \\
\text { pressure and no } \\
\text { access to } \\
\text { disability } \\
\text { pension. } \\
\text { Food vouchers } \\
\text { infrequent and } \\
\text { covered only } \\
\text { very minimal } \\
\text { amounts. }\end{array}$ & $\begin{array}{l}\text { Difficult to } \\
\text { find care for } \\
\text { sibling. } \\
\text { Increased } \\
\text { burden on } \\
\text { extended } \\
\text { family for } \\
\text { sibling care } \\
\text { and visiting } \\
\text { hospital. } \\
\text { Sibling } \\
\text { difficult } \\
\text { behaviour. } \\
\text { Financial } \\
\text { support to } \\
\text { cover part of } \\
\text { fuel costs to } \\
\text { drive to } \\
\text { hospital each } \\
\text { day. No PATS. } \\
\text { Home bills left } \\
\text { unpaid. }\end{array}$ & $\begin{array}{l}\text { Felt pushed } \\
\text { out. } \\
\text { Discharged } \\
\text { without } \\
\text { confidence. } \\
\text { Psychological } \\
\text { distress. }\end{array}$ & $\begin{array}{l}\text { Financial } \\
\text { support to } \\
\text { cover part of } \\
\text { fuel costs to } \\
\text { drive to } \\
\text { hospital each } \\
\text { day. No PATS. } \\
\text { Unable to } \\
\text { return to work } \\
\text { for almost } \\
\text { one year. } \\
\text { Long } \\
\text { appointments } \\
\text { that meant } \\
\text { whole day } \\
\text { trips. } \\
\text { Sustained } \\
\text { burden on } \\
\text { extended } \\
\text { family for } \\
\text { sibling care. }\end{array}$ \\
\hline $\begin{array}{l}\text { Child's } \\
\text { perspective } \\
(6 y 0 \text { or }>)\end{array}$ & $\begin{array}{l}\text { N/A as } \\
\text { child }<6 \text { yo }\end{array}$ & $\begin{array}{l}\text { N/A as child } \\
<6 \text { yo }\end{array}$ & $\begin{array}{l}\text { N/A as child } \\
<6 \text { yo }\end{array}$ & $\begin{array}{l}\text { N/A as child } \\
<6 \text { yo }\end{array}$ & $\begin{array}{l}\text { N/A as child }< \\
6 \text { yo }\end{array}$ & $\begin{array}{l}\text { N/A as child }< \\
\text { 6yo }\end{array}$ & $\begin{array}{l}\text { N/A as child } \\
<6 \text { yo }\end{array}$ & $\begin{array}{l}\text { N/A as child }< \\
6 \text { yo }\end{array}$ \\
\hline $\begin{array}{l}\text { Referring } \\
\text { Hospital/GP }\end{array}$ & $\mathrm{N} / \mathrm{A}$ & $\begin{array}{l}\text { Not able to } \\
\text { speak to } \\
\text { Ambulance } \\
\text { worker. } \\
\text { Case Notes: } \\
\text { identification } \\
\text { question } \\
\text { asked. }\end{array}$ & $\begin{array}{l}\text { Case Notes: } \\
\text { consideration } \\
\text { for care of } \\
\text { sibling } \\
\text { documented. }\end{array}$ & $\mathrm{N} / \mathrm{A}$ & $\mathrm{N} / \mathrm{A}$ & $\mathrm{N} / \mathrm{A}$ & $\mathrm{N} / \mathrm{A}$ & $\mathrm{N} / \mathrm{A}$ \\
\hline AHW & $\begin{array}{l}\text { No AHW } \\
\text { employed }\end{array}$ & $\begin{array}{l}\text { No AHW } \\
\text { employed }\end{array}$ & $\begin{array}{l}\text { No AHW } \\
\text { employed }\end{array}$ & $\begin{array}{l}\text { No AHW } \\
\text { employed }\end{array}$ & $\begin{array}{l}\text { No AHW } \\
\text { employed }\end{array}$ & $\begin{array}{l}\text { No AHW } \\
\text { employed }\end{array}$ & $\begin{array}{l}\text { No AHW } \\
\text { employed }\end{array}$ & $\begin{array}{l}\text { No AHW } \\
\text { employed }\end{array}$ \\
\hline A/ILO & $\mathrm{N} / \mathrm{A}$ & N/A & $\mathrm{N} / \mathrm{A}$ & $\begin{array}{l}\text { Not notified } \\
\text { child was } \\
\text { Aboriginal } \\
\text { whilst in ED. }\end{array}$ & $\begin{array}{l}\text { Supported } \\
\text { family } \\
\text { financially with } \\
\text { fuel and food } \\
\text { vouchers. } \\
\text { Helped with } \\
\text { access to } \\
\text { hospital child } \\
\text { care for sibling. }\end{array}$ & $\begin{array}{l}\text { Not resourced } \\
\text { to provide } \\
\text { support care } \\
\text { outside of the } \\
\text { hospital or to } \\
\text { those family } \\
\text { outside of the } \\
\text { hospital } \\
\text { environment. }\end{array}$ & $\begin{array}{l}\text { Arranged by } \\
\text { burn team. }\end{array}$ & $\begin{array}{l}\text { Not resourced } \\
\text { to provide } \\
\text { support. }\end{array}$ \\
\hline $\begin{array}{l}\text { Ngangkari } \\
\text { (Traditional } \\
\text { Healer) }\end{array}$ & $\begin{array}{l}\text { Not } \\
\text { requested } \\
\text { by } \\
\text { caregiver.? } \\
\text { availability. }\end{array}$ & $\begin{array}{l}\text { Not } \\
\text { requested by } \\
\text { caregiver.? } \\
\text { availability. }\end{array}$ & $\begin{array}{l}\text { Not } \\
\text { requested by } \\
\text { caregiver.? } \\
\text { availability. }\end{array}$ & $\begin{array}{l}\text { Not } \\
\text { requested by } \\
\text { caregiver.? } \\
\text { availability. }\end{array}$ & $\begin{array}{l}\text { Not requested } \\
\text { by caregiver.? } \\
\text { availability. }\end{array}$ & $\begin{array}{l}\text { Not requested } \\
\text { by caregiver. ? } \\
\text { availability. }\end{array}$ & $\begin{array}{l}\text { Not requested } \\
\text { by caregiver. } \\
\text { ? availability. }\end{array}$ & $\begin{array}{l}\text { Not requested } \\
\text { by caregiver. ? } \\
\text { availability. }\end{array}$ \\
\hline Burn Nurse & $\mathrm{N} / \mathrm{A}$ & $\mathrm{N} / \mathrm{A}$ & $\begin{array}{l}\text { Notified via } \\
\text { pager. } \\
\text { No support } \\
\text { care } \\
\text { provided. }\end{array}$ & $\begin{array}{l}\text { Attended ED } \\
\text { on arrival of } \\
\text { family. } \\
\text { Spent time } \\
\text { with } \\
\text { caregiver. } \\
\text { Provided } \\
\text { caregiver } \\
\text { with clothes } \\
\text { to change in } \\
\text { to. }\end{array}$ & $\begin{array}{l}\text { Time spent with } \\
\text { caregiver M-F to } \\
\text { ensure } \\
\text { understanding. } \\
\text { Made caregiver } \\
\text { feel } \\
\text { comfortable } \\
\text { with } \\
\text { environment. }\end{array}$ & $\begin{array}{l}\text { Encouraged } \\
\text { accessing } \\
\text { extended } \\
\text { family for } \\
\text { support with } \\
\text { sibling. }\end{array}$ & $\begin{array}{l}\text { Provided } \\
\text { written } \\
\text { instructions. } \\
\text { Gave some } \\
\text { dressings. }\end{array}$ & $\begin{array}{l}\text { Attempts to } \\
\text { make dual } \\
\text { appointments. }\end{array}$ \\
\hline $\begin{array}{l}\text { Occupational } \\
\text { Therapist }\end{array}$ & $\mathrm{N} / \mathrm{A}$ & $\mathrm{N} / \mathrm{A}$ & $\mathrm{N} / \mathrm{A}$ & $\begin{array}{l}\text { Automatic } \\
\text { referral } \\
\text { received }\end{array}$ & $\begin{array}{l}\text { Care provided } \\
\text { in ICU }\end{array}$ & $\begin{array}{l}\text { Attempts to } \\
\text { make dual } \\
\text { appointments. }\end{array}$ & $\begin{array}{l}\text { Discharge } \\
\text { advice given. }\end{array}$ & $\begin{array}{l}\text { Attempts to } \\
\text { make dual } \\
\text { appointments. }\end{array}$ \\
\hline Physiotherapist & $\mathrm{N} / \mathrm{A}$ & $\mathrm{N} / \mathrm{A}$ & $\mathrm{N} / \mathrm{A}$ & $\begin{array}{l}\text { Automatic } \\
\text { referral } \\
\text { received }\end{array}$ & $\begin{array}{l}\text { Positioning in } \\
\text { ICU }\end{array}$ & $\begin{array}{l}\text { Attempts to } \\
\text { make dual } \\
\text { appointments. }\end{array}$ & $\begin{array}{l}\text { Discharge } \\
\text { advice given. }\end{array}$ & $\begin{array}{l}\text { Seen in scar } \\
\text { clinic. }\end{array}$ \\
\hline
\end{tabular}




\begin{tabular}{|c|c|c|c|c|c|c|c|c|}
\hline $\begin{array}{l}\text { Points in time - } \\
\text { headings to } \\
\text { elicit holistic } \\
\text { views of health }\end{array}$ & Crisis & Getting help & $\begin{array}{l}\text { Leaving } \\
\text { competing } \\
\text { obligations }\end{array}$ & $\begin{array}{l}\text { Confronting } \\
\text { the system }\end{array}$ & $\begin{array}{l}\text { Sustained } \\
\text { Interactions }\end{array}$ & Being away & Going home & $\begin{array}{l}\text { Confronting } \\
\text { competing } \\
\text { needs }\end{array}$ \\
\hline $\begin{array}{l}\text { Surgeon } \\
\text { (medical staff) }\end{array}$ & $\mathrm{N} / \mathrm{A}$ & N/A & N/A & $\begin{array}{l}\text { Case Notes: } \\
\text { Informed } \\
\text { consent and } \\
\text { surgical } \\
\text { procedures. }\end{array}$ & $\begin{array}{l}\text { Case Notes: } \\
\text { Informed } \\
\text { consent and } \\
\text { surgical } \\
\text { procedures. } \\
\text { Allowed } \\
\text { caregiver to } \\
\text { give consent } \\
\text { over the phone } \\
\text { for second and } \\
\text { subsequent } \\
\text { procedures. }\end{array}$ & $\begin{array}{l}\text { Case Notes: } \\
\text { noted } \\
\text { caregiver seen } \\
\text { by social } \\
\text { worker. }\end{array}$ & $\begin{array}{l}\text { Case Notes: } \\
\text { Medical } \\
\text { review prior to } \\
\text { discharge. }\end{array}$ & $\begin{array}{l}\text { Case Notes: } \\
\text { Wound and } \\
\text { scar review as } \\
\text { necessary. }\end{array}$ \\
\hline Psychologist & $\mathrm{N} / \mathrm{A}$ & $\mathrm{N} / \mathrm{A}$ & N/A & $\begin{array}{l}\text { Case Notes: } \\
\text { no input into } \\
\text { care }\end{array}$ & $\begin{array}{l}\text { Case Notes: no } \\
\text { input into care }\end{array}$ & $\begin{array}{l}\text { Case Notes: } \\
\text { no input into } \\
\text { care }\end{array}$ & $\begin{array}{l}\text { Case Notes: } \\
\text { no input into } \\
\text { care }\end{array}$ & $\begin{array}{l}\text { Case Notes: } \\
\text { no input into } \\
\text { care }\end{array}$ \\
\hline Social Worker & N/A & N/A & N/A & $\begin{array}{l}\text { Supported } \\
\text { and sat with } \\
\text { caregiver in } \\
\text { ED } \\
\text { Explained } \\
\text { situation. } \\
\text { Explained } \\
\text { presence of } \\
\text { police officer } \\
\text { and } \\
\text { mandatory } \\
\text { notifications }\end{array}$ & $\begin{array}{l}\text { Supported } \\
\text { caregiver with } \\
\text { social health } \\
\text { and welling. } \\
\text { Ensured access } \\
\text { to fuel and food } \\
\text { vouchers. }\end{array}$ & $\begin{array}{l}\text { Provide } \\
\text { written } \\
\text { evidence to } \\
\text { support } \\
\text { disability } \\
\text { pension } \\
\text { claim. }\end{array}$ & $\begin{array}{l}\text { Ensured } \\
\text { access to fuel } \\
\text { vouchers. }\end{array}$ & $\begin{array}{l}\text { Not resourced } \\
\text { to provide } \\
\text { support once } \\
\text { discharged. }\end{array}$ \\
\hline
\end{tabular}

Table 2

- Yarning data synthesis of caregivers' experience of culturally safe care and associated risk.

\begin{tabular}{|c|c|c|c|c|c|c|c|}
\hline \multirow[t]{2}{*}{$\begin{array}{l}\text { Cultural safety } \\
\text { Principle }\end{array}$} & \multirow[t]{2}{*}{ Definition } & \multirow[t]{2}{*}{ In-Practice examples } & \multicolumn{5}{|c|}{$\begin{array}{l}\text { Caregiver's experience at } \\
\text { holistic time points } \\
\text { and associated level of risk }\end{array}$} \\
\hline & & & crisis & help & confront & sustain & home \\
\hline Reflexivity & Reflect on practice, mutual respect. & Respectful interactions. & low & low & med & med & med \\
\hline Dialogue & True engagement and consultation. & $\begin{array}{l}\text { Build rapport and dialogue with family } \\
\text { alongside consideration of kinship } \\
\text { arrangements and decision-making } \\
\text { structures, particularly as they relate to } \\
\text { children. }\end{array}$ & low & low & med & med & med \\
\hline $\begin{array}{l}\text { Power } \\
\text { imbalances }\end{array}$ & $\begin{array}{l}\text { Minimise power differentials and } \\
\text { maintain human dignity. }\end{array}$ & $\begin{array}{l}\text { Including Indigenous health workers in } \\
\text { multidisciplinary teams. }\end{array}$ & low & med & med & med & med \\
\hline Decolonisation & $\begin{array}{l}\text { Acknowledging the key role of } \\
\text { colonising history in contemporary } \\
\text { health outcomes for Aboriginal and } \\
\text { Torres Strait Islander peoples. }\end{array}$ & $\begin{array}{l}\text { Ensuring equity in healthcare to achieve } \\
\text { equity in health outcomes. }\end{array}$ & low & med & med & high & high \\
\hline Regardful care & $\begin{array}{l}\text { Provide care that is regardful of } \\
\text { culture and challenges the status quo } \\
\text { of providing care that is regardless of } \\
\text { culture. }\end{array}$ & $\begin{array}{l}\text { Patient-centred care; where the context for } \\
\text { the child and their family drives care } \\
\text { decisions. }\end{array}$ & low & low & high & high & high \\
\hline
\end{tabular}

Supplementary Material 3 - Results PJM tool Spreadsheet One. Scientific standards and family and healthcare providers meeting standards. 


\begin{tabular}{|c|c|c|c|c|c|c|c|}
\hline $\begin{array}{l}\text { Burn care } \\
\text { standards } \\
{[30-32,34,35]}\end{array}$ & The injury & $\begin{array}{l}\text { Emergency } \\
\text { care }\end{array}$ & $\begin{array}{l}\text { Ambulatory } \\
\text { care }\end{array}$ & Admission & In-patient care & Discharge & Rehabilitation \\
\hline $\begin{array}{l}\text { Standards } \\
\text { achieved by } \\
\text { healthcare } \\
\text { service and } \\
\text { healthcare } \\
\text { professionals }\end{array}$ & $\begin{array}{l}\text { - } 20 \\
\text { minutes } \\
\text { cool } \\
\text { running } \\
\text { water } \\
\text { within first } \\
3 \text { hours } \\
\text { - Remove } \\
\text { jewellery } \\
\text { and } \\
\text { clothing } \\
\text { - Cover } \\
\text { with non- } \\
\text { adherent } \\
\text { dressing } \\
\text { - Seek } \\
\text { medical } \\
\text { assistance } \\
\text { - Keep } \\
\text { warm } \\
\text { - Provide } \\
\text { access to } \\
\text { basic } \\
\text { online first } \\
\text { aid training } \\
\text { on burn } \\
\text { injury to } \\
\text { target the } \\
\text { community } \\
\text { - Ensure } \\
\text { first aid } \\
\text { courses } \\
\text { contain } \\
\text { burn first } \\
\text { aid content }\end{array}$ & & $\begin{array}{l}\text { - Burns } \\
\text { greater than } \\
5 \% \text { in children } \\
\text {. Full } \\
\text { Thickness } \\
\text { burns greater } \\
\text { than } 5 \% \\
\text { - Burns of } \\
\text { special areas } \\
\text { - Burns in } \\
\text { very young } \\
\text { - Children up } \\
\text { to their } 16 \text { th } \\
\text { birthday } \\
\text { should be } \\
\text { transferred to } \\
\text { a children's } \\
\text { burn unit } \\
\text { - Metro } \\
\text { clients access } \\
\text { tertiary } \\
\text { facilities } \\
\text { directly, and } \\
\text { outer regions } \\
\text { require } \\
\text { routine links } \\
\text { to tertiary } \\
\text { facilities } \\
\text { - Access to } \\
\text { specialist } \\
\text { service }\end{array}$ & $\begin{array}{l}\text { - Consult with a burn } \\
\text { surgeon } \\
\text { - Access to } \\
\text { physiotherapy, } \\
\text { occupational therapy, } \\
\text { social work, speech } \\
\text { pathology, nutritional } \\
\text { support, clinical } \\
\text { psychology } \\
\text { · Ambulatory burn } \\
\text { clinic provides } \\
\text { assessment and } \\
\text { dressing of minor } \\
\text { and non-severe } \\
\text { burns, rehabilitation } \\
\text { interventions, follow- } \\
\text { up burn dressing and } \\
\text { skin graft } \\
\text { management for } \\
\text { patients after } \\
\text { discharge } \\
\text { - long-term scar } \\
\text { management and } \\
\text { symptom control } \\
\text { : patient and family } \\
\text { teaching and support } \\
\text { - ongoing } \\
\text { complication risk } \\
\text { management and } \\
\text { treatment } \\
\text { - advisory service to } \\
\text { other hospitals, } \\
\text { healthcare } \\
\text { professionals and } \\
\text { community }\end{array}$ & 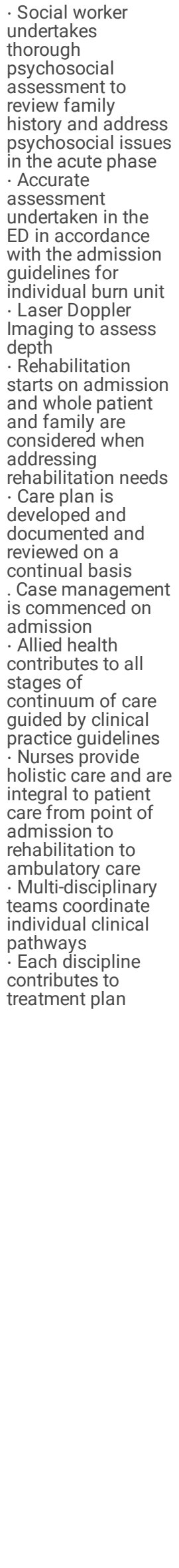 & 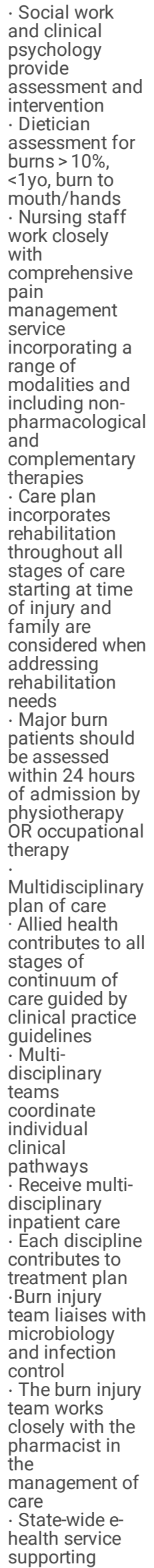 & 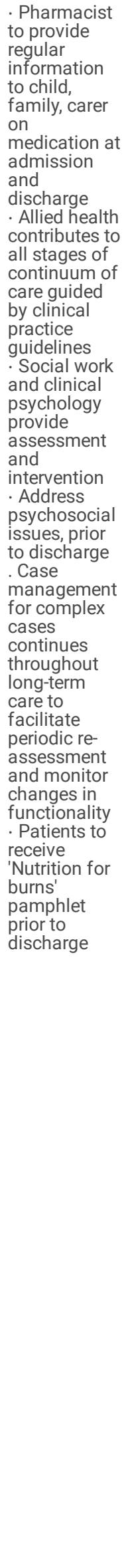 \\
\hline
\end{tabular}




\begin{tabular}{|c|c|c|c|c|c|c|c|}
\hline $\begin{array}{l}\text { Burn care } \\
\text { standards } \\
{[30-32,34,35]}\end{array}$ & The injury & $\begin{array}{l}\text { Emergency } \\
\text { care }\end{array}$ & $\begin{array}{l}\text { Ambulatory } \\
\text { care }\end{array}$ & Admission & In-patient care & Discharge & Rehabilitation \\
\hline & & & & & & $\begin{array}{l}\text { consultant-led } \\
\text { on-call advisory } \\
\text { service } \\
\text { - Patients } \\
\text { managed in ICU } \\
\text { require } \\
\text { coordination of } \\
\text { wound care by } \\
\text { burn care nurses } \\
\text { - Access to } \\
\text { pathology } \\
\text { services } \\
\cdot \text { Nursing staff } \\
\text { provide holistic } \\
\text { care } \\
\cdot 24 \text { hour access } \\
\text { to operation } \\
\text { rooms } \\
\text { - Paediatric } \\
\text { treatment rooms } \\
\text { - Child protection } \\
\text { unit involvement }\end{array}$ & \\
\hline $\begin{array}{l}\text { Standards not } \\
\text { achieved by } \\
\text { healthcare } \\
\text { service and } \\
\text { healthcare } \\
\text { professionals }\end{array}$ & & & $\begin{array}{l}\text { - Provide } \\
\text { 7day/week } \\
\text { ambulatory } \\
\text { burn service } \\
\text { co-located } \\
\text { with acute } \\
\text { inpatient burn } \\
\text { unit } \\
\text { - Burn injury } \\
\text { patients have } \\
\text { access to } \\
\text { 'hospital-in- } \\
\text { the-home' } \\
\text { services post } \\
\text { inpatient } \\
\text { discharge }\end{array}$ & $\begin{array}{l}\text { - Clinical psychology } \\
\text { provides assessment } \\
\text { and intervention at } \\
\text { admission }\end{array}$ & $\begin{array}{l}\text { - Comprehensive } \\
\text { nursing care plan } \\
\text { developed in } \\
\text { consultation with } \\
\text { patient and/or } \\
\text { caregiver on } \\
\text { admission to unit }\end{array}$ & $\begin{array}{l}\text { - Facilitated } \\
\text { early discharge } \\
\text { by accessing } \\
\text { 'hospital-in-the- } \\
\text { home' services, } \\
\text { and by using a } \\
\text { step down to } \\
\text { local non-tertiary } \\
\text { hospital for } \\
\text { transition to } \\
\text { rehabilitation }\end{array}$ & $\begin{array}{l}\text { - Use } \\
\text { telehealth for } \\
\text { ongoing post- } \\
\text { acute care of } \\
\text { burn patients } \\
\text {. } \\
\text { Rehabilitation } \\
\text { team } \\
\text { provides } \\
\text { referral to } \\
\text { external } \\
\text { rehabilitation } \\
\text { facilities for } \\
\text { ongoing } \\
\text { management } \\
\text { - Be referred } \\
\text { to OT/physio } \\
\text { at local } \\
\text { services } \\
\text { where } \\
\text { available, } \\
\text { with support } \\
\text { from burn } \\
\text { unit } \\
\text { therapists } \\
\text {. Patients and } \\
\text { families } \\
\text { continue to } \\
\text { receive } \\
\text { psychosocial } \\
\text { intervention } \\
\text { and refer to } \\
\text { other } \\
\text { agencies } \\
\text { where } \\
\text { required. }\end{array}$ \\
\hline
\end{tabular}




\begin{tabular}{|c|c|c|c|c|c|c|c|}
\hline $\begin{array}{l}\text { Burn care } \\
\text { standards } \\
{[30-32,34,35]}\end{array}$ & The injury & $\begin{array}{l}\text { Emergency } \\
\text { care }\end{array}$ & $\begin{array}{l}\text { Ambulatory } \\
\text { care }\end{array}$ & Admission & In-patient care & Discharge & Rehabilitation \\
\hline $\begin{array}{l}\text { Standards not } \\
\text { applicable for } \\
\text { this burn care } \\
\text { journey }\end{array}$ & & $\begin{array}{l}\text { - Inhalation, } \\
\text { electrical, } \\
\text { circumferential } \\
\text { and chemical } \\
\text { burns } \\
\text { - Burns with } \\
\text { illness } \\
\text { - Burns with } \\
\text { major trauma } \\
\text { - Any burn } \\
\text { where the } \\
\text { referring worker } \\
\text { requires } \\
\text { management } \\
\text { or advice from } \\
\text { the paediatric } \\
\text { burn service } \\
\text { - Burn injury } \\
\text { with suspicion } \\
\text { of non- } \\
\text { accidental } \\
\text { injury } \\
\text { - Appropriate } \\
\text { communication } \\
\text { and } \\
\text { management } \\
\text { instigated for } \\
\text { interstate } \\
\text { transfers within } \\
4 \text { hours } \\
\text { - The facility } \\
\text { who has first } \\
\text { contact with } \\
\text { the burn injury } \\
\text { contacts the } \\
\text { unit for support } \\
\text { and advice } \\
\text { - For minor } \\
\text { burns, } \\
\text { communication } \\
\text { with unit } \\
\text { regardless of } \\
\text { confidence in } \\
\text { assessment } \\
\text { and plan of } \\
\text { care } \\
\text { - For moderate } \\
\text { burn, } \\
\text { communicate } \\
\text { with unit early } \\
\text { and adopt } \\
\text { recommended } \\
\text { guidelines } \\
\text { - Laser Doppler } \\
\text { technology is } \\
\text { used to assess } \\
\text { depth } \\
\text { - Initial } \\
\text { assessment in } \\
\text { ED where staff } \\
\text { communicate } \\
\text { with state unit, } \\
\text { providing } 24- \\
\text { hour } \\
\text { turnaround } \\
\text { service via } \\
\text { email images } \\
\text { for clinical } \\
\text { advice } \\
\text { advica }\end{array}$ & $\begin{array}{l}\text { - accept } \\
\text { patients } \\
\text { referred from } \\
\text { a hospital } \\
\text { emergency } \\
\text { department, } \\
\text { general } \\
\text { practitioners, } \\
\text { other } \\
\text { hospitals, } \\
\text { community } \\
\text { health } \\
\text { services, or } \\
\text { self-referred } \\
\text { burn injury } \\
\text { of up to 10\% } \\
\text { of total body } \\
\text { surface area } \\
\text { may be } \\
\text { managed on } \\
\text { an } \\
\text { ambulatory } \\
\text { basis } \\
\text { Outpatient } \\
\text { community } \\
\text { care may } \\
\text { include home, } \\
\text { school, pre-- } \\
\text { school and } \\
\text { workplace } \\
\text { visits } \\
\text {. Referral to } \\
\text { dietician if } \\
\text { deemed to be } \\
\text { at nutritional } \\
\text { risk; followed } \\
\text { by nutritional } \\
\text { assessment } \\
\text { for social and } \\
\text { cultural needs } \\
\text { - Use of step- } \\
\text { down facility } \\
\text { to allow } \\
\text { access to } \\
\text { ambulatory } \\
\text { care services } \\
\text { for rural and } \\
\text { remote } \\
\text { families } \\
\text { - patients } \\
\text { with a burn } \\
\text { who require } \\
\text { surgery, with } \\
\text { interim burn } \\
\text { care until the } \\
\text { day of } \\
\text { surgery }\end{array}$ & $\begin{array}{l}\text { - Emergency surgery } \\
\text { within } 24 \text { hours post- } \\
\text { deep circumferential } \\
\text { burn } \\
\text { - Access to Burn Unit } \\
\text { is dependent on post- } \\
\text { assessment } \\
\text { classification of the } \\
\text { burn injury using E- } \\
\text { health Outreach } \\
\text { Service via non- } \\
\text { specialist centres for } \\
\text { regional/rural/remote }\end{array}$ & $\begin{array}{l}\text { - Education teacher } \\
\text { on daily basis } \\
\text {-Psychosocial } \\
\text { assessment } \\
\text { focussing on the } \\
\text { accident causing } \\
\text { injury and family } \\
\text { member's } \\
\text { perceptions around } \\
\text { this, past } \\
\text { experiences of } \\
\text { trauma, family } \\
\text { dynamics, cultural } \\
\text { and socio-economic } \\
\text { factors, barriers to } \\
\text { coping and family } \\
\text { strengths and } \\
\text { supports. } \\
\text { - Long term access } \\
\text { to psychological } \\
\text { support }\end{array}$ & $\begin{array}{l}\text {. Provide access } \\
\text { to } \\
\text { sub/acute/step- } \\
\text { down facilities } \\
\text { - Referral to } \\
\text { community } \\
\text { agencies for } \\
\text { support at home } \\
\text { if required }\end{array}$ & \\
\hline
\end{tabular}




\begin{tabular}{|c|c|c|c|c|c|c|c|}
\hline $\begin{array}{l}\text { Burn care } \\
\text { standards } \\
{[30-32,34,35]}\end{array}$ & The injury & $\begin{array}{l}\text { Emergency } \\
\text { care }\end{array}$ & $\begin{array}{l}\text { Ambulatory } \\
\text { care }\end{array}$ & Admission & In-patient care & Discharge & Rehabilitation \\
\hline $\begin{array}{l}\text { Standards } \\
\text { unable to be } \\
\text { assessed }\end{array}$ & & & $\begin{array}{l}\text {-Staff } \\
\text { attending } \\
\text { burn patients } \\
\text { in outpatient } \\
\text { setting } \\
\text { observe } \\
\text { standard } \\
\text { precautions } \\
\text { at all times, } \\
\text { including } \\
\text { hand hygiene } \\
\text { and aseptic } \\
\text { non-touch } \\
\text { technique } \\
\text { and relevant } \\
\text { PPE }\end{array}$ & & & & $\begin{array}{l}\text { - Step-down } \\
\text { facilities are } \\
\text { linked to } \\
\text { acute } \\
\text { services to } \\
\text { achieve a } \\
\text { seamless } \\
\text { continuum of } \\
\text { care } \\
\text {. Provide } \\
\text { access to } \\
\text { burn camps } \\
\text { for children } \\
\text {. Contribute } \\
\text { to } \\
\text { cooperation } \\
\text { between } \\
\text { family and } \\
\text { school } \\
\text {. Visit school } \\
\text { with burn } \\
\text { team to } \\
\text { educate }\end{array}$ \\
\hline \multicolumn{8}{|c|}{ Data from Case Notes and discussions (where able) regarding how standards were/were not applied } \\
\hline Caregiver & $\begin{array}{l}\text { Had } \\
\text { completed } \\
\text { first aid } \\
\text { training }\end{array}$ & & $\begin{array}{l}\text { Accessed } \\
\text { emergency } \\
\text { ambulance } \\
\text { care }\end{array}$ & $\begin{array}{l}\text { Travelled in private } \\
\text { car to appointments. } \\
\text { From daily dressing } \\
\text { to once every } 6 \\
\text { weeks. }\end{array}$ & $\begin{array}{l}\text { Time in emergency } \\
\text { department then } \\
\text { transferred to ICU. }\end{array}$ & $\begin{array}{l}\text { Four days in ICU } \\
\text { (and staying at } \\
\text { home at nights) } \\
\text { and four weeks } \\
\text { in surgical unit } \\
\text { (staying at home } \\
\text { and sometimes } \\
\text { in hospital). }\end{array}$ & $\begin{array}{l}\text { Travelled } \\
\text { home in } \\
\text { private car. } \\
\text { Felt hurried } \\
\text { out and } \\
\text { inadequately } \\
\text { prepared to } \\
\text { provide } \\
\text { necessary at- } \\
\text { home care. }\end{array}$ \\
\hline Family & N/A & & $\begin{array}{l}\text { Contacted by } \\
\text { phone after } \\
\text { accident } \\
\text { occurred }\end{array}$ & $\begin{array}{l}\text { Travelled in private } \\
\text { care with caregiver } \\
\text { occasionally }\end{array}$ & $\begin{array}{l}\text { Arrived at hospital } \\
\text { after admission to } \\
\text { ICU }\end{array}$ & $\begin{array}{l}\text { Visited often in } \\
\text { private car }\end{array}$ & \\
\hline $\begin{array}{l}\text { Aboriginal } \\
\text { Health Worker } \\
\text { (AHW) }\end{array}$ & $\begin{array}{l}\text { No AHW } \\
\text { employed }\end{array}$ & & $\begin{array}{l}\text { No AHW } \\
\text { employed }\end{array}$ & No AHW employed & No AHW employed & $\begin{array}{l}\text { No AHW } \\
\text { employed }\end{array}$ & $\begin{array}{l}\text { No AHW } \\
\text { employed }\end{array}$ \\
\hline ACCHS & $\begin{array}{l}\text { Not } \\
\text { accessed } \\
\text { by the } \\
\text { family }\end{array}$ & & $\begin{array}{l}\text { Not utilised } \\
\text { by the family }\end{array}$ & $\begin{array}{l}\text { Not accessed by the } \\
\text { family }\end{array}$ & $\begin{array}{l}\text { Not utilised by the } \\
\text { family }\end{array}$ & $\begin{array}{l}\text { Not utilised by } \\
\text { the family }\end{array}$ & $\begin{array}{l}\text { Not utilised } \\
\text { by the family }\end{array}$ \\
\hline $\begin{array}{l}\text { Emergency } \\
\text { Care Provider }\end{array}$ & $\begin{array}{l}\text { Not able to } \\
\text { contact } \\
\text { place of } \\
\text { injury or } \\
\text { those } \\
\text { present at } \\
\text { time of } \\
\text { injury }\end{array}$ & & $\begin{array}{l}\text { Not able to } \\
\text { contact } \\
\text { Ambulance } \\
\text { worker } \\
\text { Case Notes: } \\
\text { Mandatory } \\
\text { notifications } \\
\text { made }\end{array}$ & $\mathrm{N} / \mathrm{A}$ & $\mathrm{N} / \mathrm{A}$ & N/A & $\mathrm{N} / \mathrm{A}$ \\
\hline Surgeon & $\mathrm{N} / \mathrm{A}$ & & $\mathrm{N} / \mathrm{A}$ & $\begin{array}{l}\text { Consults as } \\
\text { necessary }\end{array}$ & $\begin{array}{l}\text { Surgical } \\
\text { assessment within } \\
4 \text { hours of } \\
\text { admission to } \\
\text { hospital }\end{array}$ & $\begin{array}{l}\text { Surgical } \\
\text { intervention }\end{array}$ & $\begin{array}{l}\text { Discharge } \\
\text { note made }\end{array}$ \\
\hline Burn Nurse & $\mathrm{N} / \mathrm{A}$ & & $\mathrm{N} / \mathrm{A}$ & $\begin{array}{l}\text { Arranged care } \\
\text { appointments and } \\
\text { supported caregiver } \\
\text { in minimising time } \\
\text { spent in hospital }\end{array}$ & $\begin{array}{l}\text { Support transition } \\
\text { to ICU and then to } \\
\text { ward. In regular } \\
\text { contact with } \\
\text { caregiver and giving } \\
\text { constant } \\
\text { information. }\end{array}$ & $\begin{array}{l}\text { Developed initial } \\
\text { care plan. Led } \\
\text { case } \\
\text { conferences } \\
\text { with medical } \\
\text { staff. Involved } \\
\text { multidisciplinary } \\
\text { team. Reviewed } \\
\text { at least daily. }\end{array}$ & $\begin{array}{l}\text { Gave } \\
\text { information } \\
\text { regarding } \\
\text { required care. } \\
\text { Arranged } \\
\text { follow-up } \\
\text { appointments }\end{array}$ \\
\hline A/ILO & $\mathrm{N} / \mathrm{A}$ & & & No support provision & Not notified & $\begin{array}{l}\text { On A/ILO list. } \\
\text { Seen and } \\
\text { offered support. } \\
\text { Did not attend } \\
\text { case } \\
\text { conferences. }\end{array}$ & $\begin{array}{l}\text { Seen prior to } \\
\text { discharge } \\
\text { and support } \\
\text { offered }\end{array}$ \\
\hline
\end{tabular}




\begin{tabular}{|c|c|c|c|c|c|c|c|}
\hline $\begin{array}{l}\text { Burn care } \\
\text { standards } \\
{[30-32,34,35]}\end{array}$ & The injury & $\begin{array}{l}\text { Emergency } \\
\text { care }\end{array}$ & $\begin{array}{l}\text { Ambulatory } \\
\text { care }\end{array}$ & Admission & In-patient care & Discharge & Rehabilitation \\
\hline $\begin{array}{l}\text { Traditional } \\
\text { Healer }\end{array}$ & N/A & & $\begin{array}{l}\text { No traditional } \\
\text { healer } \\
\text { employed }\end{array}$ & $\begin{array}{l}\text { No traditional healer } \\
\text { employed }\end{array}$ & $\begin{array}{l}\text { No traditional } \\
\text { healer employed }\end{array}$ & $\begin{array}{l}\text { No traditional } \\
\text { healer employed }\end{array}$ & $\begin{array}{l}\text { No traditional } \\
\text { healer } \\
\text { employed }\end{array}$ \\
\hline $\begin{array}{l}\text { Occupational } \\
\text { Therapist }\end{array}$ & N/A & & N/A & $\begin{array}{l}\text { Consults in scar } \\
\text { clinic }\end{array}$ & $\begin{array}{l}\text { Assessed within } 8 \\
\text { hours of admission }\end{array}$ & $\begin{array}{l}\text { In patient care } \\
\text { provided. } \\
\text { Attended case } \\
\text { conference. } \\
\text { Input into care } \\
\text { plan. }\end{array}$ & $\begin{array}{l}\text { Discharge } \\
\text { note made }\end{array}$ \\
\hline Physiotherapist & N/A & & $\mathrm{N} / \mathrm{A}$ & $\begin{array}{l}\text { Consults in scar } \\
\text { clinic }\end{array}$ & $\begin{array}{l}\text { Assessed within } 24 \\
\text { hours of admission }\end{array}$ & $\begin{array}{l}\text { In patient care } \\
\text { provided. } \\
\text { Attended case } \\
\text { conference. } \\
\text { Input into care } \\
\text { plan. }\end{array}$ & $\begin{array}{l}\text { Discharge } \\
\text { note made }\end{array}$ \\
\hline Psychologist & N/A & & $\begin{array}{l}\text { No input into } \\
\text { care. Not able } \\
\text { to be } \\
\text { contacted. }\end{array}$ & $\begin{array}{l}\text { No input into care. } \\
\text { Not able to be } \\
\text { contacted. }\end{array}$ & $\begin{array}{l}\text { No input into care. } \\
\text { Not able to be } \\
\text { contacted. }\end{array}$ & $\begin{array}{l}\text { No input into } \\
\text { care. Not able to } \\
\text { be contacted. }\end{array}$ & $\begin{array}{l}\text { No input into } \\
\text { care. Not able } \\
\text { to be } \\
\text { contacted. }\end{array}$ \\
\hline Social Worker & $\mathrm{N} / \mathrm{A}$ & & $\begin{array}{l}\text { Attended ED. } \\
\text { Supported, } \\
\text { engaged and } \\
\text { explained. }\end{array}$ & No input into care. & $\begin{array}{l}\text { Able to provide } \\
\text { support to caregiver } \\
\text { and available for all } \\
\text { level } 1 \text { trauma. }\end{array}$ & $\begin{array}{l}\text { Provided initial } \\
\text { assessment of } \\
\text { caregiver, } \\
\text { supported, } \\
\text { engaged and } \\
\text { provided } \\
\text { intervention } \\
\text { where necessary } \\
\text { and supported } \\
\text { access to fuel } \\
\text { and food } \\
\text { vouchers. } \\
\text { Attended case } \\
\text { conference. }\end{array}$ & $\begin{array}{l}\text { Discharge } \\
\text { note made }\end{array}$ \\
\hline
\end{tabular}

\section{Figures}




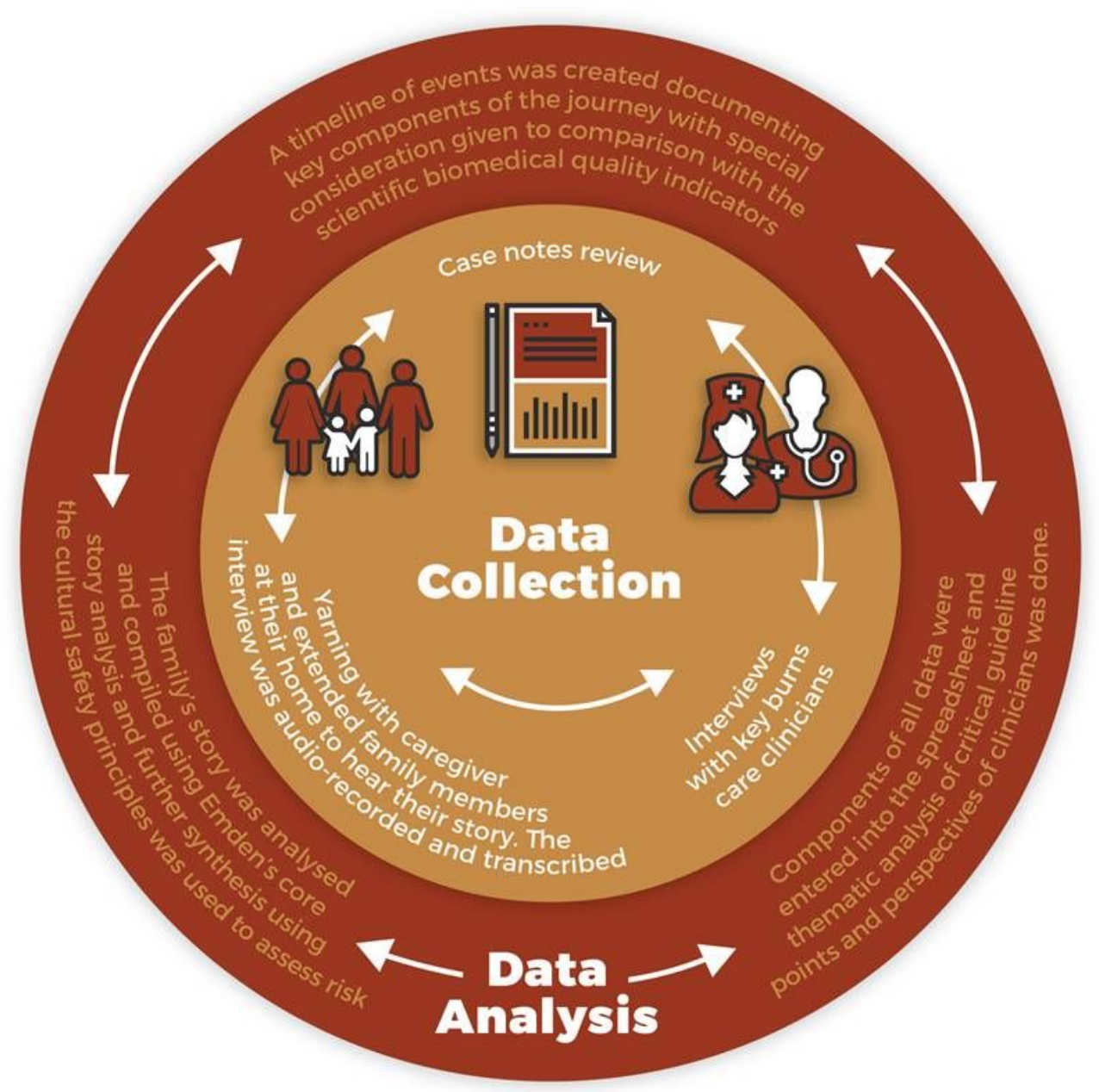

Figure 1

Data collection and data analysis mapping process

\section{Supplementary Files}

This is a list of supplementary files associated with this preprint. Click to download.

- SupplementaryMaterial1PJMToolSpreadsheetOneBestPracticeGuidelines.xIsx

- SupplementaryMaterial2PJMTooISpreadsheetTwoPatientFamilyExperience.xIsx

- SupplementaryMaterial3EmdensCoreStoryAnalysis.docx 